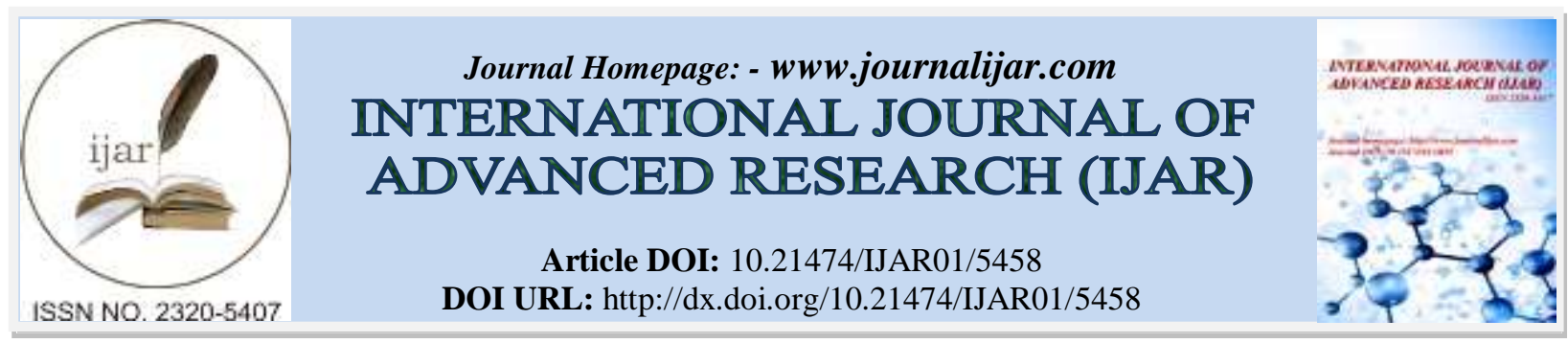

RESEARCH ARTICLE

\title{
STUDENTS' ACTIVITY IN PROBLEM-BASED LEARNING (PBL) MATH CLASSROOM BE ORIENTED LESSON STUDY FOR LEARNING COMMUNITY (LSLC).
}

Siska Ari Andini and Susanto And Hobri.

Department of Mathematics Education, University of Jember, Indonesia.

\section{Manuscript Info}

Manuscript History

Received: 18 July 2017

Final Accepted: 20 August 2017

Published: September 2017

Key words:-

problem-based learning, lesson study for learning community, collaborative learning, caring community, jumping task.

\begin{abstract}
Problem-Based Learning (PBL) be oriented Lesson Study for Learning Community (LSLC) is a learning model that begins with presentation of real problems experienced by students in everyday life so as to provide convenience to students in understanding concept or knowledge to be learned, which in the learning is contained elements of collaborative learning, caring community and jumping task. This study aims to describe students' activity using Problem-Based Learning (PBL) be oriented Lesson Study for Learning Community (LSLC) in learning. The research participants were 36 students of grade 8 on junior high school in Banyuwangi Regency, East Java, Indonesia. Data were collected through observation of learning activities, interviews, video recordings and photos. The result shows that students' activity has been according with the characteristics of Problem-Based Learning (PBL) be oriented Lesson Study for Learning Community (LSLC) in LKS by reviewing and presenting problems, developing strategi, applying strategy, discussing and evaluating the results in it elements of caring community, collaborative learning and jumping task.
\end{abstract}

Copy Right, IJAR, 2017,. All rights reserved.

\section{Introduction:-}

In 2013, the Government of Indonesia published and used the 2013 curriculum aimed at improving the quality of education. The 2013 curriculum mandates the essence of a scientific approach to learning at all levels. It is focuses on students' activity through a scientific process with the aim that creates students possessing knowledge competencies, attitude competencies and skill competencies. One of the materials underlying the development of knowledge, attitude, and skills students competencies in mathematics. The object mathematics is a product of knowledge in the form of facts, concepts, principles and skills of scientific work processes. So in the implementation of learning mathematics must achieve three main aspects of products, processes and scientific attitudes. The problems many found in learning mathematics is the low students' activity learning which later will also influence to result learn.

Based on data observation and interview with students and teacher mathematics, it is known that the problems happened in mathematics learning especially in linear equations system two variables, among others: (1) the concepts embedded in the students are still weak. Students tend to memorize concepts without understanding, (2) students' involvement in learning activities is lacking, (3) Material presentation often done by lecture and discussion methods that make teachers as teacher centered, (4) learning activities that seem monotonous and boring makes students less motivated to learn. The problems because students have difficulty in understanding the abstract 
mathematical material. These difficulties can have an unfavorable impact on students' understanding. Basically, abstract facts are an explanation for concrete facts and concepts. One indicator of the weakness learning activities is teachers domination. The dominance teachers domination resulted in less learning process that encourage students' activity to be involved and actively develop their knowledge independently. Passive learning conditions and processes will not be able to develop constructivist thinking skills in building students' idea and understanding. It causes students to have a tendency to memorize and only clever theoretically but weak in the application. Therefore, students need to be accustomed to construct knowledge independently through direct and real experience. Learning process based on constructivist theory can build students' idea, understanding, and can give deep meaning in students' memory. Ramson argues that the development of ideas or students' knowledge can be done by giving real problems experienced students in everyday life and relevant to the needs of students' knowledge. So in the learning of teachers are required to be able to package learning activities using learning models that can provide opportunities for students to explore.

Therefore, to overcome these problems required a proper model of learning, one of which is Problem-Based Learning (PBL) be oriented Lesson Study For Learning Community (LSLC). Selection of the model is tailored to the material characteristics, students' condition and student difficulty level. The PBL is a learning model that begins with the presentation of real problems then students seek and analyze problems through direct experiments or scientific studies [1]. Through this learning, students" activitiy and thinking processes become more logical, orderly, and meticulous, making it easier to understanding concept. The implementation Problem-Based Learning (PBL) consists of four stages: reviewing and presenting the problem, strategizing, applying strategi, discussing and evaluating the result [2]. The PBL is chosen because it has several advantages, among others: (1) building students' critical thinking ability and giving satisfaction to find a new knowledge; (2) can increase students' activity in learning process; (3) give opportunity of student to explore and applying their knowledge have into the real world.

Lesson Study for Learning Community (LSLC) is a lesson study has changed towards collaborative and learning community [3]. Things to consider in the implementation of LSLC is how students learn from each other and including teachers also have to learn each other (collaborative learning), caring each other and no one is neglected (caring community). The LSLC activity involves grade VIII math teacher as model teacher and teacher from another school as the observer. Problem-Based Learning (PBL) be Oriented Lesson Study for Learning Community (LSLC) can be applied to two-variable linear equations system what provide a more meaningful learning experience to students with the systematic stage of implementation so students' activity can be achieved well. Successful implementation Problem-Based Learning (PBL) be Oriented Lesson study for Learning Community (LSLC) is supported by students' activity, while teachers required to guide and facilitate student learning activities well.

This research is different from previous research, Reseach Nurina H. And Djamilah B.W aims to describe the effectiveness of PBL and PBL comparison with conventional learning in terms of critical mathematical thinking ability, mathematical and self-esteem creative thinking [4]. Research Fitri, N., et al aims to know how the influence of PBL on students' activity and learning outcomes [5]. Research Cindy and Howards aims to describe analysis of student-centered, problem-based learning facilitation. The focus of this analysis is to understand the goals and strategies of an expert in supporting collaborative learning. While in this study aims to describe the students' activity in accordance with the characteristics of Problem-Based Learning (PBL) be Oriented Lesson Study for Learning Community (LSLC) which contains elements of a caring community, collaborative learning and jumping task. Based on the above background, the research is done to describe students' activity in the linier equations system of two variables using Problem-Based Learning (PBL) be Oriented Lesson Study for Learning Community (LSLC) on junior high school in Banyuwangi Regency, East Java, Indonesia

\section{Methods:-}

This research used descriptive qualitative research type. Qualitative descriptive research is a study that describes an event with respect to the process, characteristics, quality and inter-linkages between activities occur [6]. The research participants were 36 students of grade 8 on junior high school with purposive sampling technique. The use of such techniques is based on consideration that the subject has problems identified during initial observation, class data information, and interviews with classroom teachers. The first step in this research is to arrange and validate the research instruments in the form of RPP, LKS, and tests (THB). The research instrument is validated by three validators, namely two lecturers of Mathematics Education, University of Jember and a math teacher. Validation was performed to determine the validity of the instruments used in the research. If the instrument has been valid then the instrument can be used. And if not yet valid then instrument is revised according to the validator's suggestion. 
Furthermore, the researcher determines the research area, coordinate with math teacher to determine participants and the research schedule.

Data were collected through observation of learning activities, interviews, test and questionnaires, video recordings and photos. Observation were used to obtain students' activity data and implementation Problem-Based Learning (PBL) be Oriented Lesson Study for Learning Community (LSLC) during the learning process. The observations were conducted by four observers, that is a researcher and three teachers from other schools. Interviews and questionnaires were used to determine teacher responses and student responses to the implementation of ProblemBased Learning (PBL) be Oriented Lesson Study for Learning Community (LSLC). Test were used to determine the level understanding and mastery of students materials during learning. Two tests used are student worksheet (LKS) and test (THB). Making of LKS based on the learning indicators to be achieved and the learning activities of Problem-Based Learning (PBL) be Oriented Lesson Study for Learning Community (LSLC). This LKS contains the working procedures in group discussion, the steps taken in finding a concept and solving the problems about the linier equations system of two variable. The contents of LKS play a role in instilling students' conceptual understanding through real problems, developing students' mindsets, directing students in the problem-solving process and actively engaging in group discussions.

The test (THB) contains five essays about the linier equations system of two variable with a time allocation of 60 minutes. THB also equipped with answer keys and scoring guidelines. The test results are analyzed by recap the score of each student then determine the students' learning completeness category based on Minimum Exhaustiveness Criteria (KKM). Determining classical completeness with criteria if more than or equal to $80 \%$ of the total students are able to achieve Minimum Exhaustiveness Criteria (KKM) that has been established school. [7]. Data analysis technique is qualitative descriptive analysis. The results data are processed and analyzed qualitatively. The technique used to test and convince the validity of the data is triangulation, is a method performed by the collection of fixed data from different data sources [8].

\section{Results:-}

Based on this research, the process of learning that takes place using Problem-Based Learning (PBL) be Oriented Lesson Study for Learning Community (LSLC) consists of several activities. Students' activity done in groups discussion, one group consists of four students whose adjacent seating. At the end of the study conducted final tests that aimed to determine students' understanding of the concept linier equations system of two variable. In this activity, two groups were chosen, the answers were different and represented the answers of the other groups in one class. Group 1 is encoded with K1 and group 2 is encoded with K2. Students' activity solving the problem of jumping task about linier equations system of two variable. Students are given the freedom to solve the problem by using one of the methods that graph, elimination or substitution. It aims to determine the level of students' understanding of the material that has been studied. The result of students' activity answer in group discussion can be seen in figure 1 and figure 2 .

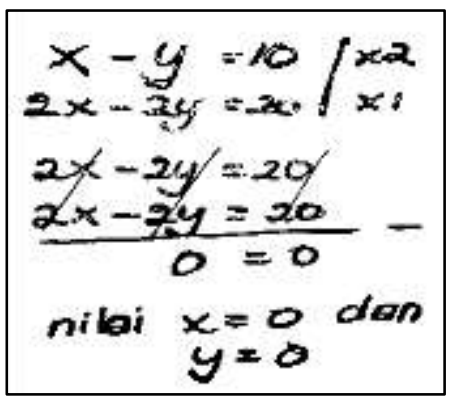

Figure 1:- K1 used elimination method.

Student activity in group K1, can reviewing and presenting the problem exactly, however compile, implementing strategies and evaluating the results are less precise. 


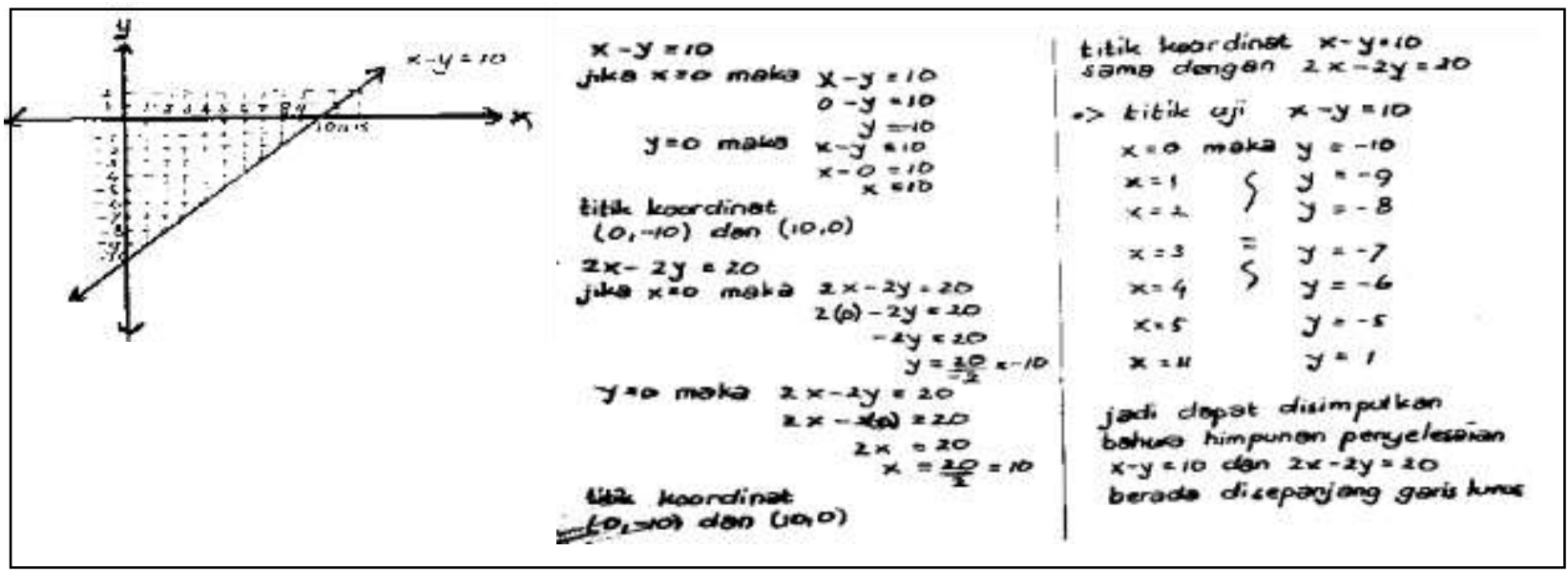

Figure 2:- K2 used Graph Method

Student activity in group $\mathrm{K} 2$, can reviewing and presenting problems appropriately, strategizing, implementing strategy and evaluating the results appropriately.

Student activity in group K1 in solving the problem of jumping task, at strategizing stage, group K1 able to involve prior knowledge in solving the problem. They choose a elimination method to determine the completion of a jumping task problem. At the stage of implementing the strategy, K1 groups apply a mutually agreed upon method of elimination but they do not know that their method use not appropriate. Group K1 thinks that all forms the linier equations system of two variable can be solved by using substitution or elimination methods. Although their method used not appropriate but the discussion conducted by group K1 runs well. It is evident that in group discussions, K1 members work together, give each other comments and suggestions when determine on a settlement, ask a group friend if there is anything less understood so that each group member feels cared and valued.

Students' activity in group K2, students write down the known and asked at the stage of reviewing and presenting the problem. At the stage of strategizing, each member of the K2 group chooses a elimination-substitution method and tries to solve individually and then compare with each work result. The results obtained are same answer. When at the stage of implementing the strategy, one group member advises using another method of graphical methods. When the equation is made graph it turns out that the results obtained are different from previous results. Then each member of the group checks coordinate point passed by a straight line to ensure that the coordinate points along the straight line represent solution the linier equations system of two variable. After making sure of the test point, the K2 group makes a conclusion. Students' activity during the learning process can be seen in figure 3.

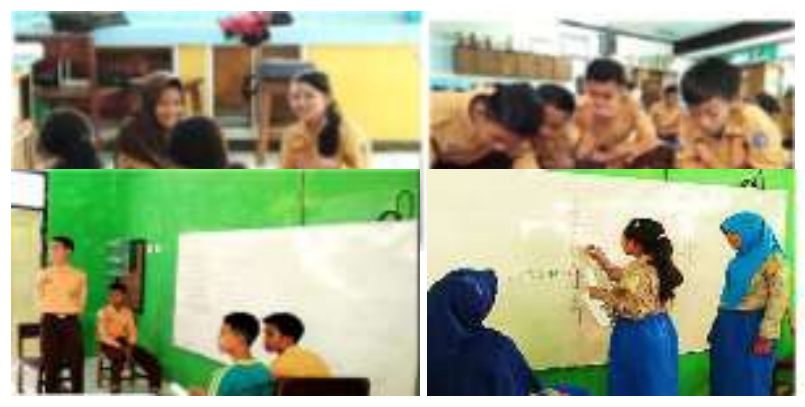

Figure 3:- students' activity in group discussion

From figure 3, it can be seen that students in groups solve the problems in the LKS. In addition, the students exchange ideas in one group or between groups (collaborative learning), exchange ideas and express opinions, mutual care for each other by providing assistance and explanation to friends if experiencing difficulties in understanding the material (caring community). 
The achievement of Student Work Sheet (LKS) in each stage of Problem-Based Learning (PBL) be oriented Lesson Study for Learning Community (LSLC) can be seen in figure 4.

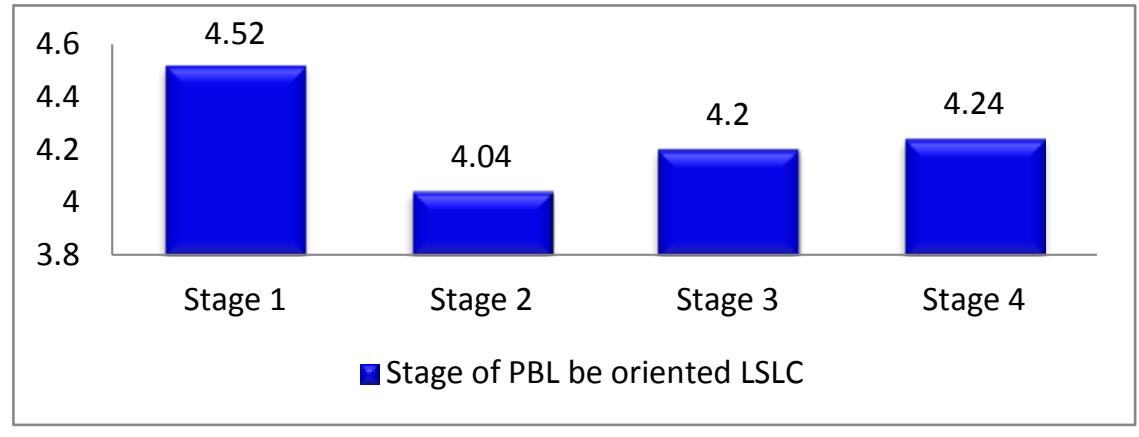

Information:-

Figure 4:- diagram stages of PBL be Oriented LSLC

Stage 1 Reviewing and presenting the problem

a. Write down what is known and asked

b. Create model illustrations

Stage 2 Strategizing, choose the method used to solve the problem

Stage 3 Implementing the strategy, using the selected method to solve the problem

Stage 4 Discussings and evaluating the results

a.Write down the results of the troubleshooting

b. Make a conclusion

c.Presenting the results of the discussion

Table 4 shows the increasing and decreasing value in each stage in Problem-Based Learning (PBL) be oriented Lesson Study for Learning Community (LSLC). The highest stage in the diagram occurs in stage 1 which is reviewing and presenting the problem with the achievement value of 4.52. In this stage, many students are able to identify tasks done by writing down the things that are known, asked and make illustrations of mathematical models. In stage 2 the value decreased 0.48 because some students have difficulty when determining the plan and choose the right way or method to solve a problem. In Stage 3 implementing the strategy achievement value of 4.2 , where students are able to construct the problem-solving process based on information that is known, asked and using the method chosen. The attainment of value in stage 4 discussing and evaluating the result is 4.2 , the student is able to test the results obtained in accordance with the question, explain the settlement coherently and make a conclusion.

\section{Discussion:-}

The implementation of Problem-Based Learning (PBL) be Oriented Lesson Study for Learning Community (LSLC) on junior high school in Banyuwangi Regency, East Java, Indonesia in the hope to encourage students' activity to be involved and actively develop their knowledge independently in building students' ideas, students' understanding and can provide deep meaning in students' memory. Problem-Based Learning (PBL) be Oriented Lesson Study for Learning Community (LSLC) is a learning that begins with a problems, where the problems are the focus that must be discussed by students. The purpose of the problems are to activate knowledge and help students to start a learning process by constructing new knowledge.

Based on the results shows that Problem Based-Learning (PBL) be Oriented Lesson Study for Learning Community (LSLC) makes the students more actively involved in meaningful learning. Students' activity is reviewing and presenting problems, strategizing, implementing the strategy, discussing and evaluating the results have a high average with the value activity of each successive stage $4.52 ; 4.04 ; 4.20$ and 4.24 . This is supported by Dewey's opinion that learning will be more meaningful if the students are actively involved in learning and reflect on the knowledge of their learning experience [9]. Students' activity occurs because social interaction students in group discussion (collaborative learning) and the sense of concern among students so that they are feel comfortable when learning (caring community). This is supported also by Vygotsky's theory that social interaction with others spurs the development of new ideas and improves the intellectual development of learners [10]. The difference of previous research results with this research is the research conducted by Clea F. (2002) showed that to get the benefit of Lesson Study, must first learn how to apply the critical lens to test the lesson. Such lenses are for example the lens 
of researchers and their role in making important lessons. [11]. Wan H.C. \& Christine A.K. (2012) resulted in a lesson study identified in an effective collaborative learning structure to support teacher effectiveness [12]. While in this research produce the description of students' activity according to a characteristic of Problem Based-Learning (PBL) be Oriented Lesson study for Learning Community (LSLC) which contains elements of collaborative learning, caring community and jumping task.

\section{Conclusion:-}

The results showed that students' activity reviewing and presenting the problem, strategizing, implementing the strategy, discussing and evaluating the result of consecutive 4,$52 ; 4.04 ; 4.20$ and 4.24 . Students often use their time to discuss or ask questions, sharing opinions or ideas to friends of one group or with other group members. Such circumstances are in accordance with the characteristics of Problem-Based Learning (PBL) be oriented Lesson Study for Learning Community (LSLC) in the LKS by reviewing and presenting the problem, strategizing, implementing the strategy, discussing and evaluating the result in which elements are contained collaborative learning, caring community, and jumping task.

\section{Suggestion:-}

Based on the results of the research, there are several suggestions to consider, among others: (1) learning with Problem-Based Learning (PBL) be Oriented Lesson Study for Learning Community (LSLC) requires a relatively large amount of time, so time allocation must be taken into account in order to implement the learning process optimally, (2) Need to reproduce the practice of the story on a regular basis. This is done so that students can understand concept and can arrange mathematical model in accordance with the problem so as to facilitate students in solving problems by performing mathematical calculations. Thus students are trained in reasoning questions.

\section{Reference:-}

1. Bridges, M. \& Hallinger, M., 1996, American Journal of Physics, 60 (7), 53-62.

2. Eggen, P., \& Kauchak, D. (2012). Strategi dan Model Pembelajaran Mengajarkan Konten dan Keterampilan Berpikir. Edisi 6. Jakarta: PT Indeks. (halaman 311)

3. Hobri, 2016, "Lesson Study for Learning Community: Review Hasil Short Term on Lesson Study V di Jepang", Prosiding Seminar Nasional Pendidikan Matematika, Tema : Peran Matematika dan Pembelajarannya dalam Mengembangkan Kearifan Budaya Lokal untuk Mendukung Pendidikan Karakter Bangsa. Jawa Timur : Universitas Madura (UNIRA), 28 Mei 2016.

4. Happy, N \& Widjajanti, D.B. (2014). Keefektifan PBL Ditinjau dari Kemampuan Berpikir Kritis dan Kreatif Matematis Serta Self-Esteem Siswa SMP. Jurnal Riset Pendidikan matematika. Vol. 1 No. 1, 48-57 https://journal.uny.ac.id/index.php/jrpm/article/viewFile/2663/2216 [17 agustus 2017].

5. Nuryanah, F., Marpaung, R.R.T., \& Yolida, B. Pengaruh Problem Based Learning Terhadap Aktivitas dan Hasil Belajar Siswa http://download.portalgaruda.org/article.php?article=373148\&val=7233\&title=PENGARUH\%20PROBLEM\%20BAS ED\%20LEARNING\%20TERHADAP\%20AKTIVITAS\%20DAN\%20HASIL\%20BELAJAR\%20SISWA[17 agustus 2017].

6. Sukmadinata. (2011). Landasan Psikologi Proses Pendidikan. Bandung: Remaja Rosdakarya, 60-90.

7. Hobri. (2010) Metodologi Penelitian Pengembangan Aplikasi pada Penelitian Pendidikan Matematika. Jember : Pena Salsabila, 58.

8. Sudijono, A. (2008). Pengantar Evaluasi Pendidikan. Jakarta : Raja Grafindo Persada. 250-255.

9. Kuhlthau, C dan R. Todd. 2007. Guided Inquiry: A Framework for Learning Through School Librariesin 21 st Century Schools. CISSL. New Jersey. (Online), (http://cissl.scils.rutgers.edu/guidedinquiry/introduction.-html.htm, [28 Maret 2015].

10. Arends, R. (2012). Learning to Teach.Ninth edition. New York: McGraww-Hill.

11. Fernandez, C. (2002). Learning from Japanese Approaches to Professional Development: The Case of Lesson Study. https://scholar.google.co.id/scholar?q=journal+lesson+study\&btnG=\&hl=en\&as_sdt=0\%2C5\&as_vis=1 [25 April 2017].

12. Chong, W.H, \& Anne, C. (2012). Teacher Collaborative Learning and Teacher Self-Efficacy: The Case of Lesson Study. http://www.tandfonline.com/doi/abs/10.1080/00220973.2011.596854 [25 April 2017].

13. Hobri \& Susanto. (2016). Collaborative Learning, Caring Community, dan Jumping Task Berbantuan Lembar Kerja Siswa Berbasis Scientific Approach: Salah Satu Alternatif Pembelajaran Matematika di Era MEA. Prosiding Seminar Nasional Pendidikan Matematika dan pembelajarannya, Tema : Peluang Matematika dan Pembelajarannya dalam menghadapi Masyarakat Ekonomi ASEAN (MEA). Jawa Timur : Universitas Jember (UNIRA), 23 Oktober 2016. 